\title{
LIKUIDITAS, SOLVABILITAS DAN PROFITABILITAS TERHADAP HARGA SAHAM
}

Mister Candera*, Ario Daffa Aji Pradana, Belliwati Kosim

RAAR $\left.\right|_{\text {Accounting Research }} ^{\text {Review of Applied }}$

Affiliation:

Accounting Department, Universitas Muhammadiyah Palembang, Indonesia

\section{* Correspondence:}

mister candera@um-

palembang.ac.id

Article Process:

Submitted:

January 20. 2022

Reviewed:

February 1, 2022

Revised:

February 5, 2022

Accepted:

February 6, 2022

Published:

February 15, 2022

\section{Citation :}

Candera. Mister, Ario

Daffa Aji Pradana,

Belliwati Kosim.(2022).

Likuiditas, Solvabilitas

Dan Profitabilitas

Terhadap Harga Saham.

RAAR: Review of

Applied Accounting

Research, 2 (1), 251-262.

Office Address:

Jl. K.H. Ahmad Dahlan,

Dukuhwaluh, Kec.

Kembaran, Kabupaten

Banyumas, Jawa Tengah

53182

e-ISSN : 2807-8969

\begin{abstract}
ABSTRAK
Penelitian ini bertujuan untuk mengetahui Pengaruh Likuiditas, Solvabilitas, Profitabilitas Terhadap Harga Saham pada perusahaan LQ45 yang Terdaftar Di Bursa Efek Indonesia. Penarikan sampel menggunakan non probability sampling dengan metode purposive sampling, sampel yang digunakan adalah 17 perusahaan. Data yang diperlukan adalah data sekunder yang di peroleh dari Bursa Efek Indonesia melalui situs www.idx.co.id dan metode pengumpulan data yaitu mengunakan metode dokumentasi. Teknik analisis yang digunakan dalam penelitian adalah tenik analisis linier berganda, uji asumsi klasik dan uji hipotesis. Hasil penelitian dari regresi linier berganda $\mathrm{Y}=(4.166-0.379 \mathrm{X} 1-0.326 \mathrm{X} 2+$ 0,204 X3 +e), uji F (Uji Simultan) dengan Fhitung sebesar 5.353> Ftabel 2.716 atau Signifikan sebesar F 0,002 <0,05 artinya ada pengaruh antara Likuiditas, Solvabilitas, Aktivitas, Profitabilitas secara bersama - sama terhadap harga saham dan uji t (Uji Parsial) pada Likuiditas thitung sebesar $-2,171<$ ttabel sebesar 1,989 dan Signifikan Likuiditas 0,033<0,05 dengan demikian dapat disimpulkan bahwa Likuiditas mempunyai pengaruh yang signifikan terhadap harga saham, pada Solvabilitas thitung sebesar $-2,570<$ ttabel sebesar 1,989 dan Signifikan Solvabilitas 0,012 < 0,05 dengan demikian dapat disimpulkan bahwa Solvabilitas mempunyai pengaruh yang signifikan terhadap harga saham, pada Profitabilitas thitung sebesar 1,513 < ttabel sebesar 1,989 dan Signifikan Profitabilitas 0,134 > 0,05 dengan demikian dapat disimpulkan bahwa Profitabilitas tidak mempunyai pengaruh yang signifikan terhadap harga saham.
\end{abstract}

Kata kunci: Likuiditas, Solvabilitas, Profitabilitas dan Harga Saham

\begin{abstract}
This study aims to determine the effect of liquidity, solvency, profitability on stock prices in LQ45 companies listed on the Indonesia Stock Exchange. Sampling using non-probability sampling with purposive sampling method, the sample used is 17 companies. The data required is secondary data obtained from the Indonesia Stock Exchange through the website www.idx.co.id and the data collection method is using the documentation method. The analysis technique used in this research is multiple linear analysis technique, classical assumption test and hypothesis testing. The results of the multiple linear regression $Y=(4.166$ $-0.379 X 1-0.326 X 2+0.204 X 3+e)$, F test (simultaneous test) with Fcount of $5.353>$ Ftable 2.716 or Significant of $F 0.002<0.05$, meaning that there is an influence between Liquidity , Solvency, Activity, Profitability together on stock prices and t test (Partial Test) on Liquidity $t$ count of $-2.171<t$ table of 1.989 and Significant Liquidity $0.033<0.05$. Thus it can be concluded that Liquidity has a significant influence on prices stocks, the Solvency tcount is $-2.570<$ ttable of 1.989 and Significant Solvency is $0.012<0.05$. Thus it can be concluded that Solvency has a significant effect on stock prices, the Profitability tcount is $1.513<$ ttable of 1.989 and Significant Profitability is $0.134>0,05$ thus
\end{abstract}


it can be concluded that profitability does not have a significant effect on stock prices.

Keywords: Liquidity, Solvency, Profitability, Stock Exchange

\section{PENDAHULUAN}

Perkembangan.ekonomi yang sangat pesat serta era globalisasi yang mempengaruhinya, mendorong masyarakat untuk dapat memaksimalkan utilitasnya untuk mencapai kesejahteraan. Selain itu juga mempengaruhi perusahaan-perusahaan yang terlibat dalam persaingan dunia usaha dengan tujuan untuk meningkatkan aktivitas perekonomian. Suatu alternatif pilihan yang dapat diambil oleh perusahaan untuk memperoleh laba dengan tujuan untuk menjaga kelangsungan jalannya perusahaan adalah dengan berinvestasi. Investasi bukan hanya berupa aktiva riil seperti tanah, emas, dan barang berharga lain, tetapi sekarang masyarakat dapat melakukan investasi melalui pasar modal.

Menurut Jogiyanto (2017) Pasar modal merupakan tempat bertemu antara pembeli dan penjual dengan risiko untung dan rugi. Pasar modal merupakan sarana perusahaan untuk meningkatkan kebutuhan dana jangka panjang dengan menjual saham atau mengeluarkan obligasi. Saham merupakan bukti kepemilikan sebagian dari perusahaan. Obligasi merupakan suatu kontrak yang mengharuskan peminjam untuk membayar kembali pokok pinjaman ditambah dengan bunga dalam kurun waktu tertentu yang sudah di sepakati.

Saham adalah tanda penyertaan atau kepemilikan seseorang atau badan dalam suatu perusahaan atau perseroan terbatas. Saham berwujud selembar kertas yang menerangkan bahwa pemilik kertas tersebut adalah pemilik perusahaan yang menerbitkan surat berharga tersebut. Porsi kepemilikan ditentukan oleh seberapa besar penyertaan yang ditanamkan di perusahaan tersebut (Darmadji dan Fakhrudin, 2011).

Harga saham merupakan harga yang terjadi di bursa pada waktu tertentu. Harga saham bisa berubah naik ataupun turun dalam hitungan waktu yang begitu cepat Ia dapat berubah dalam hitungan menit bahkan dapat berubah dalam hitungan detik. Hal tersebut dimungkinkan karena tergantung dengan permintaan dan penawaran antara pembeli saham dengan penjual saham (Darmadji dan Fakhrudin 2012).

Saham-saham yang tergabung dalam indeks LQ-45 merupakan saham yang terdiri dari 45 perusahaan sebagai indeks alternatif selain IHSG, kemudian juga sebagai pelengkap IHSG. LQ-45 dapat dijadikan sarana objektif, terpercaya oleh analis keuangan, manajer investasi dan investor dalam mengawasi pergerakan harga saham-saham di BEI. Peneliti memilih menggunakan indeks LQ-45 karena perusahaan yang masuk dalam indeks saham LQ-45 merupakan perusahaan yang mempunyai perfoma yang baik. Selain itu saham saham LQ-45 merupakan saham yang liquid atau mudah di perjual-belikan sehingga dapat membentuk portofolio dengan hasil optimal antara risiko dan tingkat pengembalian yang di harapkan. 




sumver: remums, uala yang Moran (www.mmance.yanov.com)

\section{Gambar 1 Rata-rata Harga Saham Perusahaan Indeks LQ-45}

Berdasarkan gambar 1, memberikan informasi mengenai harga rata-rata saham pada indeks LQ-45 selama 5 tahun pada periode 2015 - 2019. Dalam rata-rata harga saham diatas dapat dijelaskan bahwa rata-rata harga saham pada perusahaan indeks LQ-45 pada tahun 2015 - 2019 mengalami kenaikan pada tahun 2016-2017 mengalami kenaikan, lalu pada tahun 2018 sempat mengalami penurunan dan pada tahun 2019 mengalami kenaikan lagi. Harga saham dapat mengalami kenaikan dan penurunan (fluktuasi), naik turunnya harga saham suatu perusahaan akan mencerminkan kinerja suatu perusahaan.

Saat ini dalam praktik setidaknya ada lima jenis rasio keuangan yang sering digunakan untuk menilai kondisi keuangan dan kinerja perusahaan. Kelima jenis rasio keuangan tersebut adalah rasio likuiditas, rasio solvabilitas, rasio aktivitas, rasio profitabilitas, dan rasio penilaian atau rasio ukuran pasar (J. Fred Weston dalam Kasmir 2018). Adapun rasio-rasio keuangan yang digunakan dalam penelitian ini adalah rasio likuiditas yaitu current ratio, rasio solvabilitas yaitu debt to equity ratio dan rasio profitabilitas yaitu return on assets.

Likuiditas dengan alat ukur current ratio. Berikut ini adalah rata-rata current ratio perusahaan indeks LQ-45 pada tahun 2015 - 2019.

Gambar 2. Rata-rata Current Ratio Perusahaan Indeks LQ-45

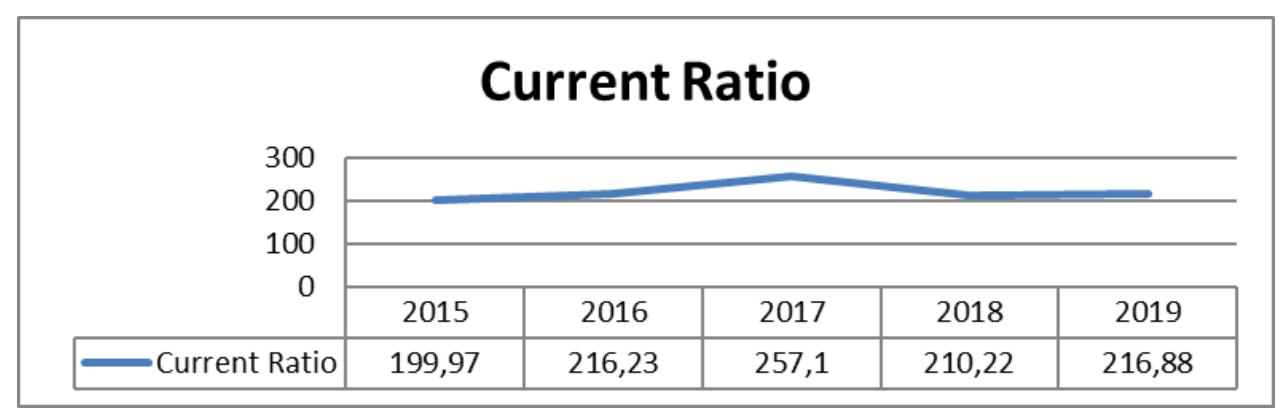

Sumber: Penulis, data yang diolah (www.idx.com)

Dalam Current Ratio tersebut dapat dijelaskan bahwa pada current ratio dalam perusahaan indeks LQ-45 pada tahun 2016-2017 mengalami kenaikan, lalu pada tahun 2018 mengalami penurunan dan pada tahun 2019 mengalami penurunan lagi. Semakin rendah tingkat current ratio suatu perusahaan akan cenderung menurunkan kualitas harga saham. Sebaliknya, semakin tinggi tingkat current ratio suatu perusahaan akan mendorong peningkatan kualitas harga saham.

Solvabilitas dengan alat akur debt to equity ratio. Berikut ini adalah rata-rata Debt to Equity Ratio perusahaan indeks LQ-45 pada tahun 2015 - 2019.

Gambar 3. Rata-rata Debt To Equity Perusahaan Indeks LQ-45 


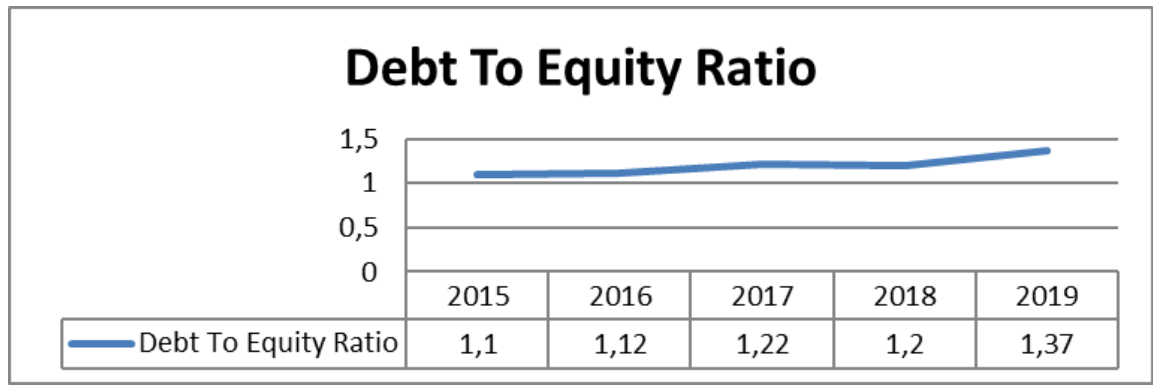

Sumber: Penulis, data yang diolah (www.idx.com)

Dalam Debt to Equity Rasio diatas dapat dijelaskan bahwa debt to equity ratio pada perusahaan indkes LQ-45 pada tahun 2016 - 2017 mengalami kenaikan, lalu pada tahun 2018 sempat mengalami penurunan dan pada tahun 2019 mengalami kenaikan lagi. Semakin rendah debt to eqity ratio maka menandakan modal asing yang digunakan dalam opersional suatu perusahaan semakin kecil, sehingga risiko yang ditanggung investor juga akan semakin kecil dan akan mampu meningkatkan harga saham suatu perusahaan.

Profitabilitas dengan alat ukur return on assets. Berikut ini adalah rata-rata Return on Assets perusahaan indeks LQ-45 pada tahun 2015-2019

Gambar 4. Rata-rata Return On Asset Perusahaan Indeks LQ-45

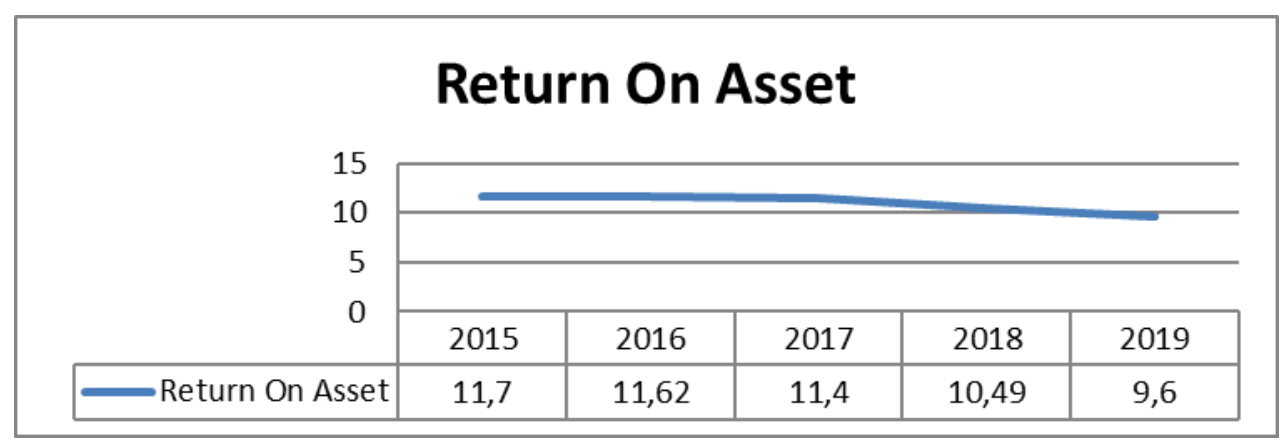

Sumber: Penulis, data yang diolah (www.idx.com)

Dalam return on assets tersebut dapat dijelaskan bahwa return on assets pada perusahaan indeks LQ-45 pada tahun 2016 - 2019 terus mengalami penurunan. Semakin kecil (rendah) rasio return on assets maka semakin kurang baik tingkat keuntungan yang dicapai perusahaan dan sebaliknya.

Rasio ini menunjukkan bahwa manajemen dapat menggunakan total aktiva perusahaan dengan baik yang pada akhirnya akan meningkatkan harga saham perusahaan sehingga menarik para investor untuk menanamkan modalnya di suatu perusahaan.

Dalam penelitian ini Periode yang diambil adalah tahun 2015 - 2019 karena data-data yang diambil adalah data yang terbaru sehingga diharapkan dapat memberikan manfaat dan informasi bagi investor untuk mengambil keputusan dalam berinvestasi, ditengah kondisi ekonomi negara yang tengah bergejolak dan sentimen-sentimen negatif dari pasar global serta sebagai informasi. 


\section{Harga Saham}

Harga saham adalah nilai saham dalam rupiah yang terbentuk akibat terjadinya aksi pembelian dan penawaran saham di bursa efek oleh semua anggota bursa (Hadi 2013). Harga saham menentukan kekayaan pemegang saham. Maksimalisasi kekayaan pemegang saham diterjemahan menjadi maksimalkan hargasaham perusahaan. Harga saham pada satu waktu tertentu akan bergantung pada arus kas yang diharapkan diterima di masa depan oleh investor "rata-rata" jika investor membeli saham (Brigham dan Houston 2010).

\section{Faktor-Faktor Yang Mempengaruhi Harga Saham}

Menurut Mahmud M Hanafi, dan Abdul Halim (2007) faktor-faktor yang mempengaruhi harga saham adalah rasio aktivitas, solvabilitas, likuiditas, dan profitabilitas.

\section{Likuiditas}

Menurut Fred Weston dalam kasmir (2018) rasio likuiditas merupakan rasio yang menggambarkan kemampuan perusahaan dalam memenuhi kewajiban jangka pendek.

Fungsi lain rasio likuiditas adalah untuk menunjukkan atau mengukur kemampuan perusahaan dalam memenuhi kewajibannya yang jatuh tempo, baik kewajiban kepada pihak luar perusahaan (likuiditas badan usaha) maupun di dalam perusahaan (Likuiditas Perusahaan). Atau dengan kata lain, rasio likuiditas merupakan yang menunjukan kemampuan perusahaan untuk membayar utangutang (kewajiban) jangka pendeknya yang jatuh tempo, atau rasio untuk mengetahui kemampuan perusahaan dalam membiayai dan memenuhi kewajiban (utang) pada saat ditagih Kasmir (2018).

\section{Solvabilitas}

Menurut kasmir (2018) leverage ratio (rasio solvabilitas) merupakan rasio yang digunakan untuk mengukur sejauh mana aktiva perusahaan dibiayai dengan utang. artinya berapa besar beban utang yang ditanggung perusahaan disbandingkan dengan aktivanya. Dalam arti luas dikatakan bahwa rasio solvabilitas digunakan untuk mengukur kemampuan perusahaan untuk membayar seluruh kewajibannya, baik jangka pendek maupun jangka panjang apabila perusahaan dibubarkan (dilikuidasi).

Menurut kasmir (2018) dalam praktiknya, apabila dari hasil perhitungan, perusahaan ternyata memiliki rasio solvabilitas yang tinggi, hal ini akan berdampak timbulnya risiko kerugian lebih besar, tetapi juga ada kesempatan mendapat laba juga besar. Sebaliknya apabila perusahaan memiliki rasio solvabilitas lebih rendah tentu memiliki resiko kerugian lebih kecil pula, terutama pada saat perekonomian menurun. Dampak ini juga mengakibatkan rendahnya tingkat hasil pengembalian (return) pada saat perekonomian tinggi.

\section{Profitabilitas}

Menurut kasmir (2018) rasio profitabilitas merupakan rasio untuk menilai kemampuan perusahaan dalam mencari mencari keuntungan. Rasio ini juga memberikan ukuran tingkat efektivitas manajemen suatu perusahaan. Hal ini ditunjukan oleh laba yang dihasilkan dari penjualan dan pendapatan investasi. Intinya adalah penggunaan rasio ini menunjukkan efisiensi perusahaan..

Penggunaan rasio profitabilitas dapat dilakukan dengan menggunakan perbandingan antara berbagai komponen yang ada dilaporan keuangan, terutama laporan keuangan neraca dan laporan laba rugi. Pengukuran dapat dilakukan untuk beberapa periode operasi. Tujuannya adalah agar terlihat perkembangan perusahaan dalam rentang waktu tertentu, baik penurunan atau kenaikan, sekaligus mencari penyebab perubahan tersebut (kasmir; 2018).

\section{METODOLOGI PENELITIAN}

Jenis penelitian yang digunakan dalam penelitian ini adalah berjenis penelitian asosiatif. untuk mengetahui pengaruh ataupun juga hubungan antara dua variabel atau lebih pada harga sahampada perusahaan lq45 yang terdaftar di bursa efek indonesia. Penelitian ini secara keseluruhan menggunakan data sekunder yang diperoleh dari situs $\underline{w w w . i d x . c o . i d}$ dan www.finance.yahoo.com

RAAR Vol.2 No.1 
Teknik pengumpulan data yang dilakukan dalam penelitian ini adalah Dokumentasi. Penelitian terhadap Harga Saham memiliki populasi 64 Perusahaan dan sampel 17 perusahaan Lq45 yang

73 terdaftar di bursa efek indonesia, Teknik pengambilan sampel yang dipilih yaitu purposive sampling yang merupakan teknik penentuan sampel dengan pertimbangan tertentu. Kriteria pengambilan sampel dalam penelitian ini adalah saham-saham yang secara berturut-turut selama 5 tahun.

Program aplikasi SPSS digunakan dalam malakukan pengujian asumsi klasik dan analisis data. Uji asumsi klasik dalam penelitian ini berupa uji normalitas, multikolinearitas dan heterokedastisitas. Dan metode analisis yang digunakan dalam penelitian ini adalah metode analisis regresi linier berganda, uji F, uji t.

Persamaa Regresi Linear Berganda :

$Y=\alpha+\beta 1 X 1+\beta 2 X 2+\beta 3 X 3$

Dimana :

$\alpha \quad$ : Bilangan Konstan

$\beta \quad$ : Koefisien Regresi

Y : Harga Saham

$\mathrm{X}_{1} \quad$ : Likuiditas

$\mathrm{X}_{2} \quad$ : Solvabilitas

$\mathrm{X}_{3} \quad$ : Profitabilitas

Gambar 5. Kerangka Pemikiran

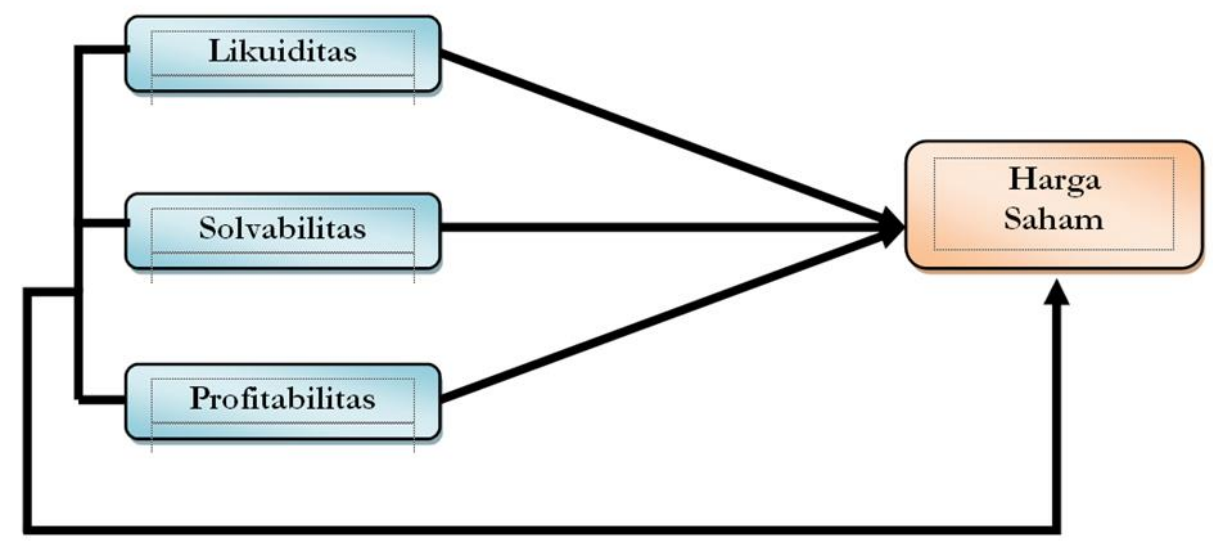

Sumber : gagasan penulis berdasarkan teori

\section{HASIL PENGUJIAN HIPOTESIS}

\section{Uji Normalitas}

Uji normalitas bertujuan untuk menguji apakah nilai residual yang dihasilkan dari regresi terdistribusi secara normal atau tidak. Hasil uji normalitas dapat dilihat pada Gambar 6:

\section{RAAR}




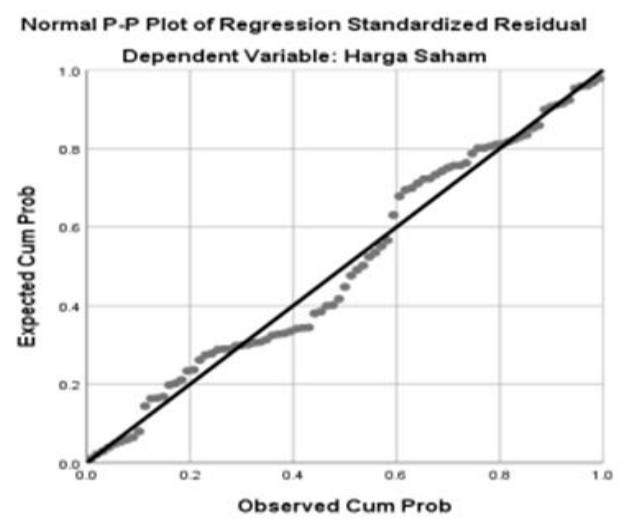

Sumber : Hasil Ouput SPSS Versi 25.2021

Berdasarkan Gambar 6 Normal P-P Plot diatas, dapat disimpulkan bahwa pola grafik berdistribusi normal, hal ini dilihat dari data yang menyebar disekitar garis diagonal. Sehingga grafik normal PP Plot di atas, dapat dikatakan baik dan layak untuk dipakai dalam penelitian karena memenuhi asumsi normalitas.

\section{Uji Multikolinearitas}

Uji multikolinearitas bertujuan untuk menguji apakah dalam model regresi ditemukan adanya korelasi yang sempurna atau mendekati sempurna antar variabel independen (bebas).Model regresi yang baik seharusnya tidak terjadi korelasi di antara variabel bebas (korelasinya 1 atau mendekati). Hasil uji multikolinearitas dapat dilihat pada Tabel 1:

Tabel 1. Uji Multikolinearitas

\begin{tabular}{llcc}
\hline \multicolumn{1}{c}{ Model } & Tolerance & VIF \\
\hline \multicolumn{1}{c}{ (Constant) } & & \\
CR & DER & .963 & 1.039 \\
& ROA & .922 & 1.085 \\
& & .920 & 1.087 \\
\hline
\end{tabular}

\section{Sumber : Hasil Ouput SPSS Versi 25.2021}

Berdasarkan hasil uji multikolinearitas pada Tabel 1, hasil yang diperoleh koefisien tolerance dan VIF menunjukkan bahwa angka tolerance pada tabel diatas mendekati angka 1 dan VIF kurang dari 10. Hal ini menunjukkan bahwa tidak terjadi multikolinearitas antar variabel independen dalam model regresi yang dibuat, sehingga model regresi ini layak untuk digunakan.

\section{Uji Heterokedastisitas}

Uji heteroskedastisitas bertujuan untuk menguji apakah dalam model regresi terjadi ketidaksamaan variansi dari residual pada satu pengamatan ke pengamatan yang lain. Model regresi yang baik adalah tidak terjadi heteroskedastisitas. Hasil uji heteroskedastisitas dapat dilihat pada Gambar 2:

Tabel 2. Uji Heterokedastisitas

\begin{tabular}{llcc|c|c|c}
\hline \multirow{2}{*}{ Model } & \multicolumn{2}{c|}{ Unstandardized Coefficients } & \multicolumn{2}{c|}{$\begin{array}{c}\text { Standardized } \\
\text { Coefficients }\end{array}$} & \multirow{2}{*}{$\mathrm{t}$} & \multirow{2}{*}{ Sig. } \\
\cline { 2 - 3 } & $\mathrm{B}$ & Std. Error & Beta & & \\
\hline 1 & (Constant) & -5.271 & 2.147 & & -2.455 & .016 \\
\hline $\mathrm{X} 1$ & 1.068 & .855 & .138 & 1.249 & .215 \\
\hline $\mathrm{X} 2$ & -.900 & .621 & -.164 & -1.450 & .151 \\
\hline $\mathrm{X} 3$ & -.081 & .660 & -.014 & -.123 & .902 \\
\hline
\end{tabular}

Sumber : Hasil Ouput SPSS Versi 25.2021 
Berdasarkan hasil uji heterokedatisitas (Park) pada Tabel 2, hasil yang diperoleh menunjukkan bahwa nilai signifikan pada tabel diatas mendekati lebih besar dari 0.05. Hal ini menunjukkan bahwa tidak terjadi heterokedastisitas antar variabel independen dalam model regresi yang dibuat, sehingga model regresi ini layak untuk digunakan.

\section{Analisis Regresi Linier Berganda}

Hasil dari data analisis diperoleh sebagai berikut:

Tabel 3. Analisis regresi linier berganda

\begin{tabular}{|c|c|c|c|}
\hline & \multirow{2}{*}{ Model } & \multicolumn{2}{|c|}{ Unstandardized Coefficients } \\
\hline & & B & Std. Error \\
\hline \multirow[t]{4}{*}{1} & (Constant) & 4.166 & 0.439 \\
\hline & CR & -0.379 & 0.175 \\
\hline & DER & -0.326 & 0.127 \\
\hline & ROA & 0.204 & 0.135 \\
\hline
\end{tabular}

Sumber : Hasil Pengolahan data SPSS Versi 25

Dari hasil regresi linier berganda yang diteliti pada variabel Likuiditas (Current Ratio), Solvabilitias (Debt to Equity Ratio), Profitabiitas (Return on Equity Ratio) terhadap harga saham dapat dugunakan sebagai berikut :

$$
Y=4.166-0.379 \times 1-0.326 \times 2+0,204 \times 3
$$

Nilai konstanta adalah 4,166 artinya jika tidak ada Likuditas, Solvabilitas, Profitabilitas, maka Harga Saham adalah 4.166.

Koefisien varibel Likuiditas (Current Ratio) bernilai negatif sebesar -0.379, hal ini mununjukkan bahwa faktor Likuiditas mempunyai pengaruh negatif terhadap harga saham. Artinya Likuiditas (Current Ratio) mengalami kenaikan 1\% maka harga saham akan mengalami penurunan sebesar 0.379. Dengan demikian perusahaan yang memiliki Current Ratio yang kecil mengindikasikan bahwa perusahaan tersebut memiliki modal kerja (aset lancar) yang sedikit untuk membayar kewajiban jangka pendeknye. Sebaliknya, apabila perusahaan memiliki Current Ratio yang tinggi, belum tentu perusahaan tersebut dikatakan baik. Sebagaimana yang telah disinggung diatas, Current Ratio yang tinggi dapat saja terjadi karena kurang efektifnya manajemen kas dan persediaan yang tidak memadai. Koefisien Solvabilitas (Debt to Equity Ratio) bernilai negatif sebesar -0,326, hal ini mununjukkan bahwa faktor Solvabilitas (Debt to Equity Ratio) mempunyai pengaruh negatif terhadap harga saham. Artinya Solvabilitas (Debt to Equity Ratio) mengalami kenaikan $1 \%$ maka harga saham akan mengalami penurunan sebesar 0,326 . Oleh sebab itu, akan lebih aman bagi kreditor apabila memberikan pinjaman kepada debitor yang memiliki tingkat Debt to Equity Ratio yang rendah karena hal ini berarti bahwa akan semakin besar jumlah modal pemilik yang dijadikan sebagai jaminan utang. Dengan kata lain, semakin tinggi Debt to Equity Ratio maka bearti semakin kecil jumlah modal pemilik yang dapatdijadikan sebagai jaminan utang. Koefisien Profitabilitas (Return on Equity Ratio) bernilai positif sebesar 0,204, hal ini mununjukkan bahwa faktor Profitabilitas (Return on Asset Ratio) mempunyai pengaruh positif terhadap harga saham. Artinya Profitabilitas (Return on Asset Ratio) mengalami kenaikan 1\% maka harga saham akan mengalami peningkatan sebesar 0,204. Hal ini berarti semakin tinggi pengembalian atas Aset maka semakin tinggi pula jumlah laba bersih yang dihasilkan dari setiap dana yang tertanam dalam total aset, demikian pula sebaliknya.

\section{RAAR} Vol.2 No.1

\section{Uji Hipotesis Secara Bersama-Sama (Uji F/Simultan)}

Berikut adalah hasil dari uji hipotesis secara Bersama-sama (Uji F/ Simultan):

Tabel 4. Uji F Simultan ANOVA $^{\mathrm{a}}$ 


\begin{tabular}{ll|c|c|c|c|c}
\hline \multicolumn{1}{c}{ Model } & $\begin{array}{c}\text { Sum of } \\
\text { Squares }\end{array}$ & Df & Mean Square & F & Sig. \\
\hline 1 & 2.590 & 3 & .863 & 5.353 & $.002^{\mathrm{b}}$ \\
\hline & Regression & 13.062 & 81 & .161 & & \\
\hline Residual & 15.652 & 84 & & & \\
\hline Total & & & & \\
\hline
\end{tabular}

Sumber: Hasil Output SPSS Versi 252021

Berdasarkan tabel 4 dijelaskan nilai signifikan 0,002 hal tersebut menggambarkan bahwa terdapat pengaruh secara simultan Kinerja Keuangan (Likuiditas, Solvabilitas, Profitabilitas) terhadap harga saham pada perusahaan indeks Lq45 yang terdaftar di bursa efek indonesia.

Berdasarkan hasil uji $\mathrm{F}$ dengan taraf nyata $\alpha=0,05$ atau $5 \%$ dan nilai $\mathrm{F}_{\text {tabel }}$ ditentukan dengan derajat kebebasan $\mathrm{V}_{1}=\mathrm{k}-1 \quad(4-1=3)$ dan $\mathrm{V}_{2}=\mathrm{n}-\mathrm{k}(85-3=82)$ sehingga di dapat nilai untuk $\mathrm{F}_{\text {tabel }}$ sebesar 2,716, maka $F_{\text {hitung }}$ sebesar $5.353>F_{\text {tabel }}$ sebesar 2,716 atau sig $F \leq \alpha(0,002 \leq 0,05)$, maka Ho ditolak dan Ha diterima, artinya ada pengaruh yang signifikan Likuiditas, Solvabilitas, profitabilitas secara simultan terhadap harga saham pada perusahaan indeks Lq45 yang terdaftar di bursa efek indonesia.

\section{Uji Hipotesis Secara Individual (Uji t)}

Berikut adalah hasil dari uji hipotesis secara individual (Uji t):

Tabel 5. Hasil Hipotesis Secara Individual (Uji t)

\begin{tabular}{|c|c|c|c|c|c|c|}
\hline & \multirow[t]{2}{*}{ Model } & \multicolumn{2}{|c|}{$\begin{array}{c}\text { Unstandardized } \\
\text { Coefficients }\end{array}$} & \multirow{2}{*}{\begin{tabular}{|c|}
$\begin{array}{c}\text { Standardized } \\
\text { Coefficients }\end{array}$ \\
Beta \\
\end{tabular}} & \multirow[t]{2}{*}{$\mathbf{t}$} & \multirow[t]{2}{*}{ Sig. } \\
\hline & & $\bar{B}$ & Std. Error & & & \\
\hline \multirow[t]{4}{*}{$\overline{1}$} & (Constant) & 4.166 & 0.439 & & 9.501 & 0.000 \\
\hline & CR & -0.379 & 0.175 & -0.225 & -2.171 & 0.033 \\
\hline & DER & -0.326 & 0.127 & -0.272 & -2.570 & 0.012 \\
\hline & ROA & 0.204 & 0.135 & 0.160 & 1.513 & 0.134 \\
\hline
\end{tabular}

Sumber : Hasil Pengolahan data SPSS Versi 25

Berdasarkan tabel 5 menunjukkan nilai ttabel dengan taraf nyata $\alpha=0,05$ atau $5 \%$ dan nilai tabel ditentukan dengan derajat kebebasan $\mathrm{t}=\mathrm{n}-\mathrm{k}-1 \quad(85-3-1=81)$ sehingga di dapat nilai $\mathrm{t}_{\text {tabel }}$ sebesar 1,989 .

Berdasarkan hasil analisa data diperoleh nilai thitung untuk variabel Likuiditas (Current Ratio) sebesar -2.171, sedangkan nilai ttable sebesar 1.989, maka thitung sebesar $-2.171<$ ttabel sebesar 1.989. Dengan demikian Ho diterima dan Ha ditolak maka dapat disimpulkan bahwa Likuiditas (Current Ratio) tidak mempunyai pengaruh terhadap harga saham.

Berdasarkan hasil analisa data diperoleh nilai thitung untuk variable Solvabilitas (Debt to Equity Ratio) sebesar -2.570 , sedangkan nilai ttable sebesar 1,989 , maka thitung sebesar $-2.570<$ ttabel sebesar 1.989. Dengan demikian Ho diterima dan Ha ditolak maka dapat disimpulkan bahwa Solvabilitas (Debt to Equity Ratio) tidak mempunyai pengaruh terhadap harga saham.

Berdasarkan hasil analisa data diperoleh nilai thitung untuk variabel Profitabilitas (Return on Asset Ratio) sebesar 1.513, sedangkan nilai ttable sebesar 1,989, maka thitung sebesar $1.513<$ ttabel sebesar 1,989. Dengan demikian Ho diterima dan Ha ditolak maka dapat disimpulkan bahwa Profitabilitas (Return on Asset Ratio) mempunyai pengaruh terhadap harga saham.

\section{Pembahasan}

\section{Pengaruh Likuiditas, Solvabilitas dan Profitabillitas Terhadap Harga Saham}

Berdasarkan pengujian data, bahwa secara simultan (Uji F) antara Likuiditas, Solvabilitas, Vol.2 No.1 Profitabilitas berpengaruh signifikan terhadap harga saham. Hal ini dapat dibuktikan dari nilai 
Fhitung sebesar 5.353 lebih besar dari Ftabel sebesar 2,716 dengan nilai signifikan sebesar 0,002 karena nilai signifikan lebih kecil dari 0,05, maka Ho ditolak dan Ha diterima. Dapat disimpulkan 77 bahwa secara simultan (Uji F) ada pengaruh yang signifikan antara Likuiditas, Solvabilitas, Profitabilitas terhadap harga saham. Menurut Darmadji dan Fakhrudin (2012) harga saham merupakan harga yang terjadi di bursa pada waktu tertentu. Harga saham bisa berubah naik ataupun turun dalam waktu yang begitu cepat. Harga saham dapat berubah dalam hitungan menit bahkan dapat berubah dalam hitungan detik. Hal tersebut dimungkinkan karena tergantung dengan permintaan dan penawaran antara pembeli saham dengan penjual saham.

Hasil ini sejalan dengan penelitian Tatang Kosasih et. al (2019) yang menyatakan bahwa Current Ratio, Debt to Equity Ratio, Return on Equity Ratio secara simultan mempunyai pengaruh terhadap harga saham.

\section{Pengaruh Likuiditas Terhadap Harga Saham}

Berdasarkan hasil analisa data variabel Likuiditas (Current Ratio) secara parsial tidak mempunyai pengaruh terhadap harga saham. Dapat dibuktikan dari nilai thitung untuk variabel Likuiditas (Current Ratio) sebesar -2.171 sedangkan nilai ttable sebesar 1,989, maka thitung sebesar $-2.171<$ ttabel sebesar 1,989. Dengan demikian Ho diterima dan Ha ditolak. Nilai Current Ratio yang kecil mengindikasikan bahwa perusahaan tersebut memiliki modal kerja (aset lancar) yang sedikit untuk membayar kewajiban jangka pendeknya. Sebaliknya, apabila perusahaan memiliki Current Ratio yang tinggi, belum tentu perusahaan tersebut dikatakan baik. Dengan kata lain, tingkat current ratio yang tinggi cenderung mendorong perusahaan untuk meningkatkan laporan keuangan pada perusahaan LQ45. Salah satunya dengan perbaikan tata kelola perusahaan atau harga saham. Oleh karena itu, dapat disimpulkan bahwa semakin tinggi tingkat current ratio perusahaan akan mendorong peningkatan kualitas harga saham. Sebaliknya, semakin rendah tingkat current ratio perusahaan akan cenderung menurunkan kualitas harga saham. Menurut Hery (2015) Current Ratio atau Rasio lancar merupakan rasio untuk mengukur kemampuan perusahaan dalam memenuhi kewajiban jangka pendeknya yang segera jatuh tempo dengan menggunakan total aset lancar yang tersedia. Dengan kata lain, rasio ini mengambarkan seberapa besar jumlah ketersediaan aset lancar yang di miliki perusahaan dibandingkan dengan total kewajiban lancar. Oleh sebab itu, rasio lancar dihitung sebagai hasil bagi antar total aset lancar dengan total kewajiban lancar.

Hasil ini didukung dengan penilitian Innes Saraswati et. al (2020), Santi Octaviani dan Dahlia Komalasari (2017), Ditha Maharani Aviliankara dan Tetty lasniroha Sarumpaet (2017) yang menyatakan bahwa current ratio tidak mempunyai pengaruh tehadap harga saham.

\section{Pengaruh Solvabilitas Terhadap Harga Saham}

Berdasarkan hasil analisa data variabel Solvabilitas (Debt To Equity Ratio) secara parsial tidak mempunyai pengaruh terhadap harga saham. Dapat dibuktikan dari nilai thitung untuk variable Solvabilitas (Debt to Equity Ratio) sebesar -2,570, sedangkan nilai ttable sebesar 1,989, maka thitung sebesar -2,570 < ttabel sebesar 1,989. Dengan demikian Ho diterima dan Ha ditolak. Debt To Equity Ratio yaitu menggambarkan sejauh mana modal dapat menutupi hutang kepada pihak luar. Semakin kecil rasio debt to equity ratio semakin baik. Perusahaan yang menggunakan sumber dana hutang akan menimbulkan beban bunga dan beban lainnya sehingga laba yang diperoleh mengalami penurunan. Hal ini menyebabkan berkurangnya jumlah para pemegang saham dan minat investor untuk investasi karena harga saham mengalami penurunan. Menurut Hery (2015) Debt to equity ratio merupakan rasio yang digunakan untuk mengukur perbandingan antara total utang dengan total aset. Dengan kata lain, rasio ini digunakan untuk mengukur seberapa besar aset perusahaan dibiayai oleh utang atau seberapa besar untang perusahaan berpengaruh terhadap pembiayaan aset.

RAAR

Hasil ini sejalan dengan penelitian Tatang Kosasih et. al (2019), Innes Saraswati et. al (2020) dan Vol.2 No.1 Santi Octaviani dan Dahlia Komalasari (2017) yang menyatakan bahwa debt to equity ratio tidak berpengaruh terhadap harga saham.

\section{Pengaruh Profitabilitas Terhadap Harga Saham}


Berdasarkan hasil analisa data variabel Profitabilitas (Return on Asset Ratio) secara parsial tidak berpengaruh terhadap harga saham. Dapat dibuktikan dari nilai thitung untuk variabel Profitabilitas (Return on Asset Ratio) sebesar 1,513, sedangkan nilai ttable sebesar 1,989, maka thitung sebesar 1.513 < ttabel sebesar 1,989. Dengan demikian Ho diterima dan Ha ditolak. Return on Asset Ratio adalah rasio yang menunjukkan efisiensi penggunaan modal sendiri. Investor melakukan investasi untuk mendapatkan pengembalian atas uang yang telah ditanam, rasio ini menunjukkan berapa besar pengembalian tersebut. Maka, semakin besar rasio ini akan menarik minat investor untuk berinvestasi pada perusahaan tersebut. Menurut Hery (2015) Hasil pengembalian aset atau Return on Asset Ratio merupakan rasio yang menunjukkan seberapa besar kontribusi aset dalam menciptakan laba bersih. Dengan kata lain, rasio ini digunakan untuk mengukur seberapa besar jumlah laba bersih yang akan dihasilkan dari setiap rupiah dana yang tertanam dalam total aset. Rasio ini dihitung dengan membagi laba bersih terhadap asset.

Hasil ini sejalan dengan penilitian Ines Saraswati et. al (2020) dan Nitta Fitriani et.al (2016) menyatakan bahwa Return on Asset Ratio tidak berpengaruh terhadap harga saham.

\section{KESIMPULAN, KETERBATASAN DAN SARAN}

Berdasarkan hasil penelitian di atas maka dapat disimpulkan sebagai berikut: Ada pengaruh Likuiditas, Solvabilitas dan Profitabilitas terhadap Harga Saham pada Indeks Lq45 yang terdaftar di Bursa Efek Indonesia. Tidak ada pengaruh Likuiditas terhadap Harga Saham pada Indeks Lq45 yang Terdaftar di Bursa Efek Indonesia Tidak ada pengaruh Solvabilitas terhadap Harga Saham pada Indeks Lq45 yang Terdaftar di Bursa Efek Indonesia Tidak ada pengaruh Profitabilitas terhadap Harga Saham pada Indeks Lq45 yang Terdaftar di Bursa Efek Indonesia.

\section{Saran}

Berdasarkan kesimpulan diatas Maka saran yang peneliti berikan adalah sebagai berikut : Bagi peneliti selanjutnya sebaiknya menambahkan periode pengamatan sebab semakin lama interval waktu pengamatan maka semakin besar pula kesempatan untuk memperoleh informasi mengenai variabel yang lebih baik untuk penelitian yang akurat. Bagi para investor diharapkan untuk memperhatikan kondisi keuangan perusahaan terlebih dahulu yang dapat mempengaruhi harga saham. Bagi Akademik, hasil penelitian ini diharapkan bisa dijadikan sebagai acuan dan bahan referensi untuk melakukan penelitian lanjutan dan diharapkan dapat menambah faktor-faktor lain yang dapat mempengaruhi harga saham.

\section{REFERENSI}

Hanafi, M. H. dan A. H. (2007). Analisis Laporan Keuangan, edisi 3 (Vol. 26). Yogyakarta: UPP STIM YKPN.

Hanafi, Mahmud dan Abdul Halim, (2012), Analisis Laporan Keuangan. Yogyakarta: (UPP) STIM YKPN.

Ghozali, Imam. 2013. Aplikasi Analisis Multivariate dengan Program IBM SPSS 21. Semarang: Undip.

Werang, Basilius Raden. 2015. Pendekatan Kuantitatif dalam Penelitian Sosial. Yogyakarta: Calpulis.

Darmadi, Hamid. 2013. Metode Penelitian Pendidikan dan Sosial. Bandung: Alfabeta.

Husnan, Suad. (2013). Manajemen KeuanganEdisi Keempat.Yogyakarta : BPFE.

Jogiyanto.2017. Teori Portofolio Dan Analisis Investasi.Edisi Kesebelas.Penerbit BPFE.Jogjakarta.

Sugiyono. 2014. Metode Penelitian Pendidikan Pendekatan Kuantitatif, Kualitatif, dan R\&D. 
Sugiyono. 2017. Metode Penelitian Pendidikan Pendekatan Kuantitatif, Kualitatif, dan R\&D. Bandung: Alfabeta.

Sugiyono. 2018. Metode Penelitian Pendidikan Pendekatan Kuantitatif, Kualitatif, dan R\&D. Bandung: Alfabeta.

Kasmir. 2016. Analisis Laporan Keuangan. Jakarta: Rajawali Pers.

Kasmir. 2018. Analisis Laporan Keuangan. Jakarta: Rajawali Pers.

Widioatmojo, sawidji. 2011. Cara Sehat Investasi di Pasar Modal. Jakarta: PT Elex Media

Darmadji, T ., dan Fakhruddin, H (2011)., Pasar Modal di Indonesia. Salemba Empat

Darmadji, T ., dan Fakhruddin, H (2012)., Pasar Modal di Indonesia. Salemba Empat

Nor Hadi. 2013. Pasar Modal : Acuan Teoritis Dan Praktis Investasi Di Instrument Keuangan Pasar Modal. Yogyakarta: Graha Ilmu.

Brigham, Eugene F. Dan J.F. Houstoun. 2010. Dasar-Dasar Manajemen Keuangan . Edisi 11. Jakarta: Salemba Empat.

Tandelin, Eduardus. 2010. Portofolio dan Investasi: Teori dan Aplikasi. Edisi Pertama. Yogyakarta: BPFE-Yogyakarta

Sekaran, Uma dan Roger Bougie, (2017), Metode Penelitian untuk Bisnis: Pendapatan Pengembangan-Keahlian, Edisi 6, Buku 2, Salemba Empat.

www.idx.co.id

$\underline{\text { www.finance.yahoo,com }}$ 